\title{
Supervisão Ministerial das Agências Reguladoras: Limites, Possibilidades e o Parecer AGU no AC - 05।
}

Alexandre Santos de Aragão'

\section{Introdução}

Este artigo pretende discutir a legalidade e a constitucionalidade do Parecer $\mathrm{n}^{\circ} \mathrm{AC}-051$, originário do Parecer no AGU/MS 04/2006, aprovado pelo Exmo. Sr. Advogado-Geral da União e pelo Exmo. Sr. Presidente da República, conforme publicação constante da p. 01 da Seção I do $D O U$, de 19 de junho de 2006. ${ }^{2}$

Referido parecer-normativo, por força de sua aprovação presidencial, passou a apresentar, na forma do art. $40, \mathbb{S} 1^{\circ}$, da Lei Complementar $n^{9} 73 / 93$, efeitos normativos, possuindo a natureza de um ato administrativo normativo infralegal dados os seus efeitos genéricos e abstratos para todos os órgãos e entidades da Administração Federal.

O parecer-normativo, no seu corpo e nos respectivos vistos, em apertada síntese, estabelece a possibilidade de os Ministérios reverem os atos das agências reguladoras de ofício ou mediante pedido/recurso da parte interessada sempre que a agência, alegadamente, ultrapassar os limites das suas competências ou violar as políticas públicas estabelecidas pela Administração Central. No entender da AGU, quando a agência viola ou formula políticas públicas, estaria agindo fora de suas competências, sendo cabível, portanto, a atuação ministerial revogando ou anulando atos seus.

1 Professor-adjunto de Direito Administrativo da Universidade do Estado do Rio de Janeiro (UERJ). Professor do Mestrado em Regulação e Concorrência da Universidade Candido Mendes. Professorvisitante do Instituto de Economia da Universidade Federal do Rio de Janeiro (UFRJ). Professor de Pós-graduaçāo da Fundação Getulio Vargas (FGV) (Rio de Janeiro e São Paulo). Doutor em Direito do Estado pela Universidade de São Paulo (USP). Mestre em Direito Público pela UERJ. Procurador do Estado do Rio de Janeiro. Advogado (alexaragao@zipmail.com.br).

2 O presente trabalho é oriundo de parecer solicitado pela Associação Brasileira das Agências de Regulação (ABAR) acerca do tema (www.abar.org.br). 
A nosso ver, entretanto, a posição adotada pela AGU necessita de urgente revisão, pelas razões discutidas no âmbito do presente trabalho.

\section{Autonomia das agências reguladoras}

As agências reguladoras independentes constituem um modelo institucional de Administração Pública, influenciado pelo arquétipo originário dos Estados Unidos da América, que vem sendo adotado na América Latina e na Europa com especial intensidade a partir da década de 80 .

O que constitui o núcleo essencial do conceito das agências reguladoras independentes, em relação ao modelo tradicional de Administração Pública dita piramidal, napoleônica ou hierarquizada, é a independência em relação ao Poder Executivo central, independência esta que, tecnicamente, é melhor caracterizada como uma "autonomia reforçada" em relação à que possuem os demais aparatos da Administração Indireta, havendo a insurgência de uma Administração Pública Pluricêntrica $^{3}$ ou Multiorganizativa. ${ }^{4}$

Nunca é demais lembrar que toda autonomia é, por definição, limitada; autonomia é a liberdade de agir dentro de limites fixados por uma instância normativa superior. ${ }^{5}$ Não há, assim, um conceito unívoco de autonomia, que só pode ser formulado em relação a cada autonomia concretamente considerada, uma vez que os mencionados limites podem variar imensamente.

Podemos afirmar, dessa maneira, que todas as entidades da Administração Indireta possuem alguma autonomia, mas temos uma espécie de entidade da Administração Indireta - as agências reguladoras independentes - cuja autonomia, se comparada com a maioria das demais, é mais intensa, já que as suas leis instituidoras fixam competências próprias e garantias para o exercício delas de forma bem mais firme da que faz a legislação ordinariamente.

\footnotetext{
3 VITAL MOREIRA, citando BREUER, considera o surgimento de órgãos e entidades públicas autônomas em relação ao Poder estatal central como a "resposta necessária do moderno Estado social ao alargamento das suas tarefas. A autonomizaçāo de organismos administrativos é, portanto uma conseqüenncia, em termos de diferenciação e especialização, da ampliaçāo e diversificaçāo das tarefas administrativas" (MOREIRA, Vital. Administração autônoma e associaçōes públicas. Coimbra: Coimbra Editora, 1997, p. 30, 31 e 35).

4 "A Administraçāo italiana é - como, aliás, todas as Administraçōes dos países desenvolvidos - multiorganizativa, no sentido de que a amplitude e a variedade das funçōes públicas não apenas levaram à perda da unidade da organização do Estado, mas levaram-no também a adotar diversos modelos organizativos. As administrações públicas são, portanto, fragmentadas e diferenciadas. Por este motivo, é preferível dizer que a administração é multiorganizativa, antes que pluralística ou policêntrica. Estes termos muitas vezes não se referem a sujeitos, mas individuam apenas o primeiro (fragmentaçāo), e não o segundo (diferenciação), dos dois caracteres acima indicados" (CASSESE, Sabino. Le basi del diritto amministrativo, Milão: Garzanti, 6. ed., 2000, p. 189-190).

5 "A autonomia de toda instituiçāo nāo é absoluta, podendo ser apenas relativa, resultando a sua configuração de determinadas variáveis" (ROMANO, Santi. L'ordinamento giuridico. Firenze: Sansoni 2. ed., 1945, p. 22).
} 
As agências reguladoras, apesar das variaçōes que possuem em cada direito positivo e mesmo no interior de cada um deles, podem, no Direito Positivo Brasileiro, ser identificadas pela conjunção de quatro fatores:

(i) competências regulatórias, ou seja, atribuiçōes normativas, administrativas stricto sensu e contratuais, pelas quais o Estado, de maneira restritiva da liberdade privada ou meramente indutiva, determina, controla, ou influencia o comportamento dos particulares, evitando que lesem os interesses sociais definidos no marco da Constituição e orientando-os em direções socialmente desejáveis;

(ii) procedimento especial de nomeação dos membros do seu colegiado diretor, com a prévia aprovação pelo Poder Legislativo (no caso da Uniāo, pelo Senado Federal) dos nomes indicados pelo Chefe do Poder Executivo;

(iii) autonomia orgânica, sendo os seus dirigentes nomeados por prazo determinado, vedada a exoneração ad nutum e sem prévio contraditório; e

(iv) autonomia funcional, pela qual constituem a última instância administrativa - vedação de anulação ou revogação dos seus atos pelo Poder Executivo central ( $\Rightarrow$ vedação do recurso hierárquico impróprio ou de revisão ex officio), que apenas pode fixar as diretrizes gerais de políticas públicas a serem seguidas, observadas, naturalmente, as políticas já previamente estabelecidas pelo Poder Legislativo.

As agências reguladoras possuem, portanto, do ponto de vista da autonomia frente ao Executivo central, dois pontos básicos da sua própria existência conceitual: vedação de exoneração ad nutum e ser a última instância no âmbito da Administração Pública. Sem um deles, a entidade poderá até continuar existindo, mas seguramente não será mais uma agência reguladora.

O parecer-normativo da AGU coloca em xeque, portanto, a própria existência das agências reguladoras no Brasil: estaria ele declarando a incompatibilidade das agências reguladoras com o nosso sistema jurídico, por exemplo, por essa autonomia reforçada ser incompatível com o regime presidencialista? Seria ele a sede adequada para tanto? Ou, ao revés, estaria o parecer-normativo afirmando que, na verdade, nunca houve agências reguladoras entre nós, em razão, por exemplo, da disciplina do Decreto-lei nº 200/67? Essas as questões que pretendemos analisar nesta oportunidade.

No substrato da criação das agências reguladoras está a conveniência em se dar maior garantia à segurança jurídica das empresas que realizam investimentos de longo prazo, facilitando a movimentação dos capitais globalizados, e em possibilitar que a persecuçāo de políticas públicas precipuamente legislativas igualmente de longo prazo fique relativamente imune às variaçōes de curto e médio prazo da arena político-partidária, imunidade sem a qual a sua implementação teria grandes chances de ficar comprometida por interesses parciais passageiros. 
Quanto à vedação da exoneração ad nutum (autonomia orgânica), após uma grande polêmica inicial, ${ }^{6}$ o Supremo Tribunal Federal (STF) reviu a posição anteriormente sumulada (Súmula 25: "A nomeação a termo nāo impede a livre demissão, pelo Presidente da República, de ocupante de cargo dirigente de autarquia") para afirmar, na Ação Direta de Inconstitucionalidade n 1949-0, em sede liminar, a constitucionalidade do modelo institucional. $O$ relevante desta decisão do STF é a afirmação de que um Poder Executivo presidencialista, mais especificamente o nosso presidencialismo, tal como configurado na $\mathrm{CF} / 88$, não implica necessariamente em um Executivo centralizador e napoleônico, que possa determinar o comportamento de todas as entidades da Administraçāo.

Quanto à autonomia funcional (última instância administrativa), a polêmica existiu, mas, pelo menos até a edição do parecer-normativo em exame, não chegou a ser tão intensa, até porque seria ilógico e inútil assegurar todo um arcabouço institucional de proteção da autonomia, inclusive com "mandato" dos seus dirigentes e receitas próprias, se o Executivo central pudesse rever as suas decisões, convolando as agências em apenas uma etapa do processo administrativo a ser percorrido pelos administrados.

Entretanto, com a emissão do parecer-normativo em exame, a autonomia funcional das agências reguladoras está a merecer redobrado debate e afirmação, para evitar o retrocesso institucional que ele pode propiciar.

\section{Relações das agências reguladoras com o Poder Executivo Central e a fixação de políticas públicas}

O parecer-normativo sustenta a possibilidade de intervenção ministerial (mediante recurso hierárquico impróprio ou revisão ex officio) sobre as agências reguladoras sempre que estas violarem as políticas públicas fixadas pelo Executivo Central, uma vez que estariam, em assim procedendo, excedendo as suas competências institucionais.

Nāo há dúvidas de que as agências reguladoras estão adstritas às políticas públicas traçadas na Constituição, nas respectivas leis setoriais e, por derradeiro, nos instrumentos do Executivo central legalmente especificados. A política pública é, portanto, precipuamente, a da lei. Como constata o publicista português VITAL MOREIRA em relação à nossa atual conjuntura,

“a verdade é que as agências reguladoras brasileiras enfrentam agora um desafio político, que contesta a sua própria filosofia como autoridades independentes. A sua lógica está em justamente estabelecer uma separação entre a definição de opções de política regulatória, que devem ser do foro

\footnotetext{
6 Em virtude da "estabilidade temporária" dos seus dirigentes, estes nāo podem ser exonerados livremente pelos agentes legitimados democraticamente através das eleiçōes - especialmente pelo Presidente da República.
} 
governamental e permanecer dentro da esfera do 'comércio político' e sob o império das orientaçōes mutáveis de cada governo, e a regulação econômica e 'técnica' propriamente dita, que deve ser desgovernamentalizada, depender somente da lei e ficar isenta de orientações governamentais, porque deve constituir um quadro estável, seguro e previsível para a economia, ou seja, para os empresários e investidores. [...] Mas, esclarecido esse problema de fronteiras do seu mandato, as agências reguladoras independentes têm toda a justificação, tanto para garantir uma regulação imparcial lá onde o Estado concorre com operadores privados, ao longo do processo de liberalização, como para garantir, com autoridade em relação aos operadores, públicos ou privados, as obrigações de serviço público ligadas à generalidade das utilities (energia elétrica, telecomunicações, etc.)".?

Não é fácil, todavia, distinguir a formulação das políticas públicas (atribuição do Poder Executivo central) da sua implementação (atribuição das agências), até porque ambas interagem em uma relação circular e dialética, o que faz com que o parecer-normativo, nos termos em que foi lavrado, seja uma carta-branca em favor do Executivo central, que sempre poderá invocar uma suposta política pública quando quiser intervir na agência, cabendo à AGU - órgão do próprio Executivo central - o papel de juiz supremo desse conflito. Isso porque integra o próprio conceito de política pública uma imensa fluidez e constante adaptação às mudanças da realidade socioeconômica subjacente, fazendo com que "política pública" e a "implementação da política pública" funcionem de forma circular e retro-operativa. ${ }^{8}$

Não há, portanto, como tecer uma delimitação minimamente precisa do que sejam as políticas públicas e de até que ponto pode atuar o Executivo central sem ingressar no âmbito da sua implementação ou de até onde pode atuar a agência sem que seja acusada de violar políticas públicas. É intuitivo, portanto, que fixar o cabimento de determinado recurso com base na delimitação dessas competências enseja uma válvula de escape para todos os interesses contrariados pela agência, sejam particulares, sejam da Administração Pública central, violando todo o ar-

MOREIRA, Vital. Agências reguladoras independentes em xeque no Brasil. In: MARQUES, Maria Manuel Leitāo; MOREIRA, Vital. A māo visivel: mercado e regulaçāo. Coimbra: Almedina, 2003, p. 228-229.

8 Em um dos poucos conceitos de política pública elaborados pela doutrina jurídica brasileira, Fábio Konder Comparato afirma que "a primeira distinção a ser feita, no que diz respeito à política como programa de ação, é de ordem negativa. Ela não é uma norma nem um ato, ou seja, ela se distingue nitidamente dos elementos da realidade jurídica, sobre os quais os juristas desenvolveram a maior parte de suas reflexōes [...] Mas, se a política deve ser claramente distinguida das normas e dos atos, é preciso reconhecer que ela acaba por englobá-los como seus componentes. É que a política aparece, antes de tudo, como uma atividade, isto é, um conjunto organizado de normas e atos tendentes à realização de um objetivo determinado. [...] Constitui o cerne da moderna noçāo de serviço público, de procedimento administrativo e de direção estatal da economia. A política, como conjunto de normas e atos, é unificada pela sua finalidade. Os atos, decisōes ou normas que a compõem, tomados isoladamente, são de natureza heterogênea e submetem-se a um regime jurídico que lhes é próprio" (COMPARATO, Fábio Konder. Juízo de Constitucionalidade das Políticas Públicas, in Estudos em Homenagem a Geraldo Ataliba, São Paulo: Malheiros, 1997, v. 2, p. 352/533). 
cabouço institucional conferido às agências reguladoras justamente para assegurar que esses interesses sejam regulados de forma técnica, independente e eqüidistante.

Percebe-se, portanto, que, a prevalecer o entendimento adotado no parecernormativo, a definição do que sejam políticas públicas, essencial que é para a apreciação da sua violação, será realizada casuisticamente, muitas vezes com base em juizos atécnicos ou até mesmo determinada por interesses políticos e arbitrários, causando uma enorme e injustificada insegurança jurídica, bem como o desvirtuamento do arcabouço institucional das agências reguladoras.

É em vista disso que a doutrina, antecipando os problemas oriundos desse tipo de controle, afirma o caráter excepcional do recurso hierárquico impróprio e da revisão ex officio, com a necessidade de previsão expressa do seu cabimento em lei, conforme se verá nos próximos tópicos.

\section{Caráter excepcional do recurso hierárquico impróprio e da revisão ex officio e necessidade de previsão expressa em lei}

É de grande relevância a questão das decisões das agências reguladoras de se sujeitarem ou não a recursos hierárquicos impróprios, e a fortiori à revisão ex officio, isto é, de serem passiveis de revisão pela Administração central, seja pelo Conselho de políticas públicas do setor, pelo Ministro competente ou pelo Presidente da República.

DIOGO FREITAS DO AMARAL os define como sendo "recursos administrativos mediante os quais se impugna um acto praticado por um órgão de certa pessoa colectiva pública perante outro órgão da mesma pessoa colectiva que, não sendo superior do primeiro, exerça sobre ele poderes de superintendência" e observa que não obstante a proximidade destes com os recursos hierárquicos próprios, a sua natureza é distinta, pois que fundamentada em relação de tutela administrativa, e não de hierarquia. ${ }^{10} \mathrm{E}$, por isso, o autor os denomina de recursos tutelares. ${ }^{11}$

Examinando o Direito brasileiro positivo, de pronto podemos afirmar que nenhuma lei prevê a existência de recurso administrativo hierárquico impróprio contra as decisões das agências reguladoras, o que por si só bastaria para eliminar tal possibilidade em razão da vetusta doutrina do pas de tutelle sans texte, pas de tutelle au-delà du texte, ${ }^{12}$ decorrente da personificação jurídica das entidades da

\footnotetext{
9 AMARAL, Diogo Freitas. Conceito e natureza do recurso hierárquico, Coimbra: Almedina, 2005, p. 127.

10 AMARAL, Diogo Freitas. Conceito e natureza do recurso hierárquico. p. 129-130.

AMARAL, Diogo Freitas. Conceito e natureza do recurso hierárquico. p. 147.

12 "O controle administrativo ou tutela administrativa, segundo generalizada lição doutrinária, exerce-se nos limites da lei. Não se presume. Existirá quando, como e na forma prevista em lej" (BANDEIRA DE MELLO, Celso Antônio. Curso de direito administrativo, 11. ed. São Paulo: Malheiros, 1999, p. 147, grifamos).
} 
Administração Indireta, que não são meros órgãos despersonalizados - partes integrantes do corpo do Ente estatal.

A esse respeito, expōe MARIA SYLVIA ZANELLA DI PIETRO que o controle administrativo é o gênero do qual fazem parte a tutela, a autotutela e o controle hierárquico, traçando a diferença entre os dois últimos e o conceito de tutela, modalidade de controle aplicável às agências reguladoras independentes como entidades da Administraçāo Indireta. ${ }^{13}$ Quanto ao recurso hierárquico impróprio, a autora observa que, em geral, não cabem recursos contra atos da Administração Indireta perante a Administração Direta. Esta modalidade de recurso é excepcional e só pode ser manejada se houver previsão legal expressa, de forma que, "com exceção dessa hipótese, nas demais, prolatada a decisão final pelo dirigente da entidade, somente cabe ao interessado recorrer ao Poder Judiciário". ${ }^{14}$

Ora, não há, seja na Constituição Federal, no Decreto-lei nº 200/67 ou nas leis das agências reguladoras uma referência sequer a recurso hierárquico impróprio. Aliás, nesse sentido, HELY LOPES MEIRELLES ensina que "a autarquia não age por delegação; age por direito próprio e com autoridade pública, na medida do 'jus imperii' que lhe foi outorgado pela lei que a criou. Como pessoa jurídica de Direito Público Interno, a autarquia traz ínsita, para a consecução de seus fins, uma parcela do poder estatal que lhe deu vida. Sendo um ente autônomo, não há subordinação hierárquica de autarquia para a entidade estatal a que pertence, porque se isto ocorresse anularia o seu caráter autárquico. Há, por parte do Estado, simples tutela administrativa, expressa no poder de controle finalístico do serviço autárquico". ${ }^{15}$

Essa tutela, diz o autor, pode assumir diversas formas, preventivas e repressivas, mas "desde que tais modalidades estejam previstas em lei e se indiquem os atos que as ensejam, o processo respectivo, e a autoridade competente para a decisão correcional". O mesmo se diga quanto ao recurso hierárquico impróprio, cujo manejo, de acordo com o autor, deve ser excepcional e, justamente em vista disso, "torna-se necessária a sua admissibilidade por lei e a prévia regulamentação de seu processo e de seus efeitos". ${ }^{16}$

\footnotetext{
13 "Há diferenças sensíveis entre tutela e hierarquia: a tutela nāo se presume, pois só existe quando a lei a prevê; a hierarquia existe independentemente de previsāo legal, porque é princípio inerente à organização administrativa do Estado; a tutela supōe a existência de duas pessoas jurídicas, uma das quais exercendo controle sobre a outra, existindo onde haja descentralização administrativa; a hierarquia existe dentro de uma mesma pessoa jurídica, relacionando-se com a idéia de desconcentração; a tutela é condicionada por lei, ou seja, só admite os atos de controle expressamente previstos; a hierarquia é incondicionada e implica uma série de poderes que lhe são inerentes, como o de dar ordens, o de rever os atos dos subordinados (ex officio ou mediante provocaçāo), o de avocar e delegar atribuições." DI PIETRO, Maria Sylvia. Direito administrativo. São Paulo: Atlas, 2004, p. 409.

14 DI PIETRO, Maria Sylvia. Direito administrativo. São Paulo: Atlas, 2004, p. 411.

15 MEIRELLES, Hely Lopes. Autarquias e entidades paraestatais. RT, Sāo Paulo, v. 51, n 322, p. 22, ago. 1962.

16 MEIRELLES, Hely Lopes. Autarquias e entidades paraestatais, p. 26-27.
} 
Como se vê, a doutrina, de forma geral, refuta as conclusões adotadas pelo parecer-normativo da $\mathrm{AGU}$, defendendo que o recurso hierárquico impróprio não pode ser genericamente extraído da supervisão ministerial ou, muito menos, do regime presidencialista, sendo imprescindível a sua previsão legal expressa e específica. E nem se diga que tal possibilidade decorreria do direito de petição previsto pela Constituição Federal, pois, quanto à necessária possibilidade de interposição de recursos administrativos, presumindo que isto possa ser extraído do art. $5^{\circ}, \mathrm{LV}$, $\mathrm{CF}$, as leis das agências e os atos regulamentares e regimentais que as regulamentam já prevêem recursos internos à própria agência (ex.: art. 10 , VI e $\mathbb{\$} 2^{\circ}$, Lei $n^{0}$ 9.961/00 e art. $9^{\circ}$, IX, MP $\mathbf{n}^{0} 2.219 / 01$ ), atendendo-se à exigência constitucional.

Ademais, a admissão de recursos hierárquicos impróprios deitaria por terra todo o arcabouço institucional traçado pelo ordenamento jurídico para as agências reguladoras, tornando inócua, por exemplo, a vedação de exoneração ad nutum dos seus dirigentes. $\mathrm{O}$ espírito da disciplina destas entidades, que é justamente o de afastá-las das injunções político-eleitorais fugazes e casuísticas, restaria totalmente corrompido se o Ministro ou o Presidente da República pudesse a qualquer momento impor, caso a caso, a sua vontade pela simples alegação de violação de política pública.

Dessa forma, JESSÉ TORRES PEREIRA JÚNIOR sustenta que o controle exercido sobre as entidades da Administraçāo indireta deve ter limites, para que o ente tutelado não se transforme "em um joguete do Poder Central, negando a razão de ser do próprio instituto". ${ }^{17}$ Ora, "a presunção é de que a entidade vinculada possui condições técnicas para conduzir os assuntos afetos ao seu campo de trabalho, sendo este de tal natureza que exigiu fosse a sua execução descentralizada e confiada a entidade especialmente para esse fim. Não faz sentido, portanto, confundir-se supervisão com execução subordinada ou condicionada". ${ }^{18}$ Dentre estes limites, o autor cita, em primeiro lugar, as leis de cada entidade.

Aliás, essa distinção é feita pelo próprio Decreto-lei no 200/67, ao tratar do controle ministerial sobre os órgãos da Administração Direta e sobre as entidades da Administração Indireta em artigos distintos, ressaltando, ainda, no inciso IV do seu art. 26, que tal supervisão deverá assegurar a autonomia administrativa, operacional e financeira da entidade da Administração Indireta, não fazendo a mesma ressalva para os órgãos da Administração direta. Tal diferenciação fundamenta-se no fato de que a supervisão ministerial sobre órgãos da administração direta é pautada em relação de natureza hierárquica, ao passo que a supervisão sobre entidades da administração indireta é fundamentada em relação de tutela. É também eloqüente o fato de o Decreto-lei no 200/67, ao enunciar os diversos instrumentos de supervisão ministerial (art. 26, parágrafo único), não fazer qualquer referência ao recurso hierárquico impróprio.

PEREIRA JÚNIOR, Jessé Torres. Supervisão ministerial e tutela administrativa. Arquivos do Ministério da Justiça, v. 33, nº 139, jul./set. 1976, p. 158.

18 PEREIRA JÚNIOR, Jessé Torres. Supervisāo ministerial e tutela administrativa, p. 159. 
O Superior Tribunal de Justiça já se manifestou a respeito da abrangência da supervisão ministerial prevista pelo Decreto-lei $n^{\circ} 200 / 67$, no julgamento do Mandado de Segurança n ${ }^{\circ}$ 8.810/DF, que é de especial relevância para o presente estudo. Nessa decisão, com base em julgado do Supremo Tribunal Federal, o STJ entendeu que a supervisão ministerial prevista no Decreto-lei no 200/67 não compreende a competência para o julgamento dos recursos hierárquicos impróprios. Assim, referido julgado deixa claro que a admissāo do recurso hierárquico impróprio sem previsão legal expressa viola mesmo o princípio da legalidade, já que ele é um instrumento processual que deve constar de lei, e como não é referido pelo Decreto-lei $\mathrm{n}^{\mathrm{a}} \mathbf{2 0 0 / 6 7}$, haveria de sê-lo na lei específica de instituição da entidade para que pudesse ser cabível.

Parece-nos, portanto, com respaldo na doutrina e na jurisprudência dos nossos Tribunais superiores, que a possibilidade de interposição de recurso hierárquico impróprio depende necessariamente de previsão legal expressa e deve ser limitada a casos excepcionais.

Por fim, cumpre esclarecer que, ao contrário do que pretende fazer crer o parecer-normativo da AGU, a inadmissibilidade de recursos hierárquicos impróprios, impedindo o controle hierárquico do Poder Executivo sobre as Agências, não significa a livre e arbitrária atuação delas no ordenamento jurídico. Percebe-se que o controle político do Poder Executivo não é o único nem o mais intenso exercido sobre a atuação das agências. Além dele, há também o controle pelo Poder Legislativo, pelo Judiciário, pelo Ministério Público e pela própria população.

O nosso ordenamento jurídico já prevê, portanto, outros meios de controle, inclusive pelo próprio Executivo. Os controles exercidos pelo Poder Executivo sobre as agências reguladoras, contudo, serāo apenas aqueles típicos das pessoas jurídicas integrantes da Administração Indireta, ou seja, de tutela administrativa ou de supervisão ministerial. O recurso hierárquico impróprio é, na verdade, uma contradição nos próprios termos: instaura uma relaçāo hierárquica, ou seja, de substituibilidade, onde essa não poderia existir em razão da existência de personalidades jurídicas distintas. Daí o adjetivo pouco confortável do "impróprio".

\section{O Decreto-lei n 200/67 e as figuras da supervisão ministerial e da avocação presidencial}

O parecer-normativo em questão fundamenta em parte o cabimento dos recursos hierárquicos impróprios na previsão genérica da supervisão ministerial sobre as entidades da Administração Pública contida na Constituição Federal (especialmente no art. $87, \$ 1^{\circ}$, II) e no Decreto-lei $n^{\circ} 200 / 67$, bem como na avocatória presidencial prevista no art. 170 deste último.

O Decreto-lei no $200 / 67$, editado em plena ditadura militar, trata da organização da Administração Pública Federal, tendo procurado introduzir, à época, 
uma reforma administrativa. Não obstante a sua importância na instituição de métodos e técnicas de trabalho para a administração pública brasileira, que se encontram, em parte, em vigor até os dias atuais, a doutrina chama a atenção para alguns equívocos que podem advir da sua interpretação desavisada.

O primeiro deles diz respeito à errônea presunção de que o referido diploma legal disciplina de forma imutável e absoluta a estrutura da Administração Pública federal. MARÇAL JUSTEN FILHO ensina que "é usual que se examine, indevidamente, a disciplina do Dec.-lei $n^{0} 200$ tal como fosse a solução final e imutável da esquematização do poder estatal no Brasil. Isso envolve equívocos significativos e acarreta problemas cujas manifestações são inevitáveis". ${ }^{19}$

Nesse particular, o autor esclarece que "o Dec.-lei n” 200 não tem hierarquia normativa superior a nenhuma lei federal ordinária". Ademais, "a criação de novas entidades da Administração Pública depende (direta ou indiretamente) de lei, que terá a mesma hierarquia do Dec.-lei $n^{0} 200$, que foi recepcionado pela CF $/ 88 \mathrm{com}$ status de lei federal. Deste modo, a partir da CF/88, deve-se reconhecer que esse diploma se configura como uma simples lei federal; logo, aplicar-se-ão os princípios gerais da temporalidade e da especialidade". ${ }^{20}$

Assim, o Decreto-lei nº 200/67 pode ser revogado por Lei federal posterior ou excepcionado em virtude da aplicaçāo da lei especial criadora de cada entidade da Administração Indireta. E não poderia ser diferente, considerando que foi editado há quase 40 anos, em um contexto político e econômico distinto, no qual, inclusive, não existia a figura da autarquia dotada de autonomia reforçada. No que diz respeito às autarquias, MARÇAL JUSTEN FILHO observa que a sua lei de criação poderá prever um regime jurídico próprio e específico, mesmo que contrário ao previsto no Decreto-lei n 200/67. Isso porque “toda disciplina do Dec--lei no 200 , que não tenha sido incorporada constitucionalmente, pode ser modificada por lei federal posterior. Logo, sua organizaçāo, as competências a ela atribuídas, os processos de controle, a intensidade e a extensão dos vínculos entre autarquia e Administração direta - tudo isso deverá ser determinado para o caso concreto pela lei instituidora". ${ }^{21}$

Um segundo problema referente à aplicação do referido decreto-lei diz respeito à abrangência de expressōes como "supervisão ministerial" e "vinculada", que, de acordo com JESSÉ TORRES PEREIRA JÚNIOR, refletem a transposição de termos inerentes à técnica de administração para um diploma legal, mas sem

JUSTEN FILHO, Marçal. Novos sujeitos na Administração Pública: os consórcios públicos criados pela Lei Federal $n^{\circ}$ 11.107. In: OSÓRIO, Fábio Medina; SOUTO, Marcos Juruena Villela (Coord.). Direito administrativo: estudos em homenagem a Diogo de Figueiredo Moreira Neto. Rio de Janeiro: Lúmen Júris, 2006, p. 681.

20 JUSTEN FILHO, Marçal. Novos sujeitos na administração pública: os consórcios públicos criados pela Lei Federal $n^{\circ} 11.107$, p. 681-682.

${ }^{21}$ JUSTEN FILHO, Marçal. Novos sujeitos na administração pública: os consórcios públicos criados pela Lei Federal n² 11.107, p. 682. 
"a necessária categorização jurídica". ${ }^{22}$ De acordo com o autor, essa utilização de termos de natureza não jurídica impõe ao administrado e ao jurista "cautelas severas", com vistas a não "falsearem os fins pretendidos pelo DL 200/67, pelo uso equívoco dos meios neles previstos, ainda que por intermédio de impropriedades jurídicas". 23

A possibilidade de revogação de dispositivos do Decreto-lei n² 200/67 por lei posterior, bem como da instauração de relaçōes de especialidade entre ele e as leis de criação das agências reguladoras, por sua vez, possui grande relevância para a identificação da amplitude da supervisão sobre essas entidades.

Conforme visto, a supervisão ministerial foi introduzida no texto constitucional, razão pela qual não pode ser excluída pelas leis de criação das Agências Reguladoras. No entanto, a Constituição Federal não define o que seja essa supervisão e também contempla a figura da Administração Indireta (ex., art. 37, caput), o que pressupōe a descentralização, ou seja, a inexistência de relação hierárquica. ${ }^{24} \mathrm{Da}$ "qualidade de pessoa jurídica se extrai uma vida própria no plano administrativo e financeiro, distinguindo-se, por menor que seja a sua autonomia, dos serviços hierarquizados do Estado. A gestão direta é substituída por uma gestão própria, no sentido mais elementar do termo". ${ }^{25}$

Assim, todas as medidas de supervisão previstas no Decreto-lei nº 200/67 que contrariarem as leis das agências reguladoras e a própria conceituação constitucional de entidade da Administração Indireta não lhes são aplicáveis.

Dessa forma, mesmo que o Decreto-lei no $200 / 67$ previsse o recurso hierárquico impróprio como um dos instrumentos de controle ministerial sobre as agências reguladoras - o que não faz -, as leis das agências reguladoras teriam o condão de afastá-lo em virtude do critério da especialidade. Na verdade, mesmo as leis das agências reguladoras que não estabelecem expressamente serem elas "autoridades independentes" ou a "última instância administrativa", ao regularem exaustivamente o seu regime autonômico derrogariam o Decreto-lei no 200/67, nos termos do art. $2^{\circ}$, $\mathbb{1} 1^{\circ}$, da Lei de Introdução ao Código Civil.

Nesse contexto, o que o parecer-normativo opera é, muito além da mera diferenciação formalmente afirmada, uma equiparação substancial entre os meros órgãos desconcentrados da Administração Direta e os entes personalizados da Administração Indireta, em sentido contrário a toda lógica constitucional da descentralização administrativa e em evidente afronta às leis especiais das agências reguladoras.

\footnotetext{
22 PEREIRA JÚNIOR, Jessé Torres. Supervisão ministerial e tutela administrativa, p. 127.

23 PEREIRA JÚNIOR, Jessé Torres. Supervisāo ministerial e tutela administrativa, p. 127.

24 Conforme expōe HOMONT, "não há descentralização pelo simples fato de ser conferida personalidade jurídica e autonomia financeira" (Cf. THERON, Jean-Pierre. Recherche sur la notion d'établissement public. Paris: LGDJ, 1976, p. 43).

25 THERON, Jean-Pierre. Recherche sur la notion d'établissement public. Paris: LGDJ, 1976, p. 48.
} 
O mesmo se diga quanto à avocatória presidencial, prevista no art. 170 do Decreto-lei nº 200/1967, não possuindo correspondência na Constituição Federal: "art. 170. O Presidente da República, por motivo relevante de interêsse público, poderá avocar e decidir qualquer assunto na esfera da Administração Federal". De acordo com REGIS FERNANDES DE OLIVEIRA, "avocar é o ato do hierarca que traz para si a competência que é do subalterno", ${ }^{26}$ de forma que, nas palavras de MIGUEL S. MARIENHOFF, “a avocação é, pois, uma conseqüência do poder hierárquico". ${ }^{27}$

Como se vê, a avocação é um instrumento próprio das relações de natureza hierárquica, caracterizada pela constante sujeição de um órgão a outro e na qual há uma total possibilidade de ingerência do órgão superior sobre o inferior, uma vez que a competência deste último é compreendida na do primeiro. ${ }^{28} \mathrm{O}$ termo, utilizado pelo art. 170 do Decreto-lei n⿳⼈ㅡㄹ 200/67, só pode, naturalmente, ser tomado em seu sentido técnico, sendo aplicável, portanto, apenas aos órgãos da Administração Direta. E mais, ainda que, quando foi editado o mencionado dispositivo, fosse aplicável às entidades da Administração Indireta, nāo o seria mais em razão da previsāo constitucional da Administraçāo Indireta em um Estado democrático de Direito, e da derrogação operada pelas leis específicas das agências reguladoras.

Isso porque as agências reguladoras nāo são, por óbvio, hierarquicamente subordinadas ao Presidente da República, mas fazem parte de uma relação de direção, através da qual lhe são fixadas diretrizes e controlados os resultados, o que implica a sua incompatibilidade com o instrumento da avocação. Existe aí, portanto, um conflito entre lei especial - leis criadoras das agências - que prevêem a autonomia das agências frente ao Poder Executivo central, e a lei geral - o Decreto-lei $n^{0} 200 / 67$, devendo ser a última afastada em tudo aquilo em que for incompatível com a primeira, e, por conseguinte, também na parte em que prevê a avocação presidencial, já que conflitante com relações de simples direção ou tutela e com a autonomia reforçada assegurada às agências reguladoras.

Mesmo que pudéssemos cogitar o cabimento da avocação de competências das agências reguladoras, esta não poderia ser utilizada como argumento a favor dos recursos hierárquicos impróprios, uma vez que consubstanciam instrumentos completamente distintos: a avocação só pode ocorrer quando o ato a ser praticado pelo órgão inferior ainda não se consumou, de forma que, para REGIS FERNANDES DE OLIVEIRA, "se o agente subalterno já se manifestou, há preclusão para o superior" ${ }^{29} \mathrm{O}$ recurso hierárquico impróprio, por sua vez, se dá ontologicamente em um momento posterior à prática do ato. Dessa forma, a previsão da avocação não equivale à previsão do recurso hierárquico impróprio ou da revisão ex officio.

26 OliVEIRA, Regis Fernandes de. Delegaçāo e avocação administrativa. São Paulo: Revista dos Tribunais, 2004, p. 183.

2: MARIENHOFF, Miguel S. Tratado de derecho administrativo, Abeledo Perrot, 1969, t. 1, p. 547.

28 GIANNINI, Massimo Severo. Diritto amministrativo. Milāo: Giuffrè Editore, 1993, v. 1, p. 311 1-333.

29 OLIVEIRA, Regis Fernandes de. Delegação e avocação administrativas, p. 193. 
Diante do exposto no presente tópico, conclui-se que a previsão genérica de supervisão ministerial e de avocação presidencial não tem o condão de impingir às agências a revisão das suas decisões finais, a uma porque não abrangem a figura do recurso hierárquico impróprio, e a duas porque as leis de criação das agências, especiais em relação ao Decreto-lei no 200/67, prevêem a sua autonomia reforçada frente ao Poder Executivo, autonomia esta incompatível com o recurso hierárquico impróprio, com a avocação presidencial - não prevista na Constituição - e com a revisão ex officio de suas decisões.

De toda sorte, a Lei do Processo Administrativo Federal (Lei $n^{\circ}$ 9.784/99) em seu art. 15 coloca a avocação como um instituto de utilização excepcional e temporária, sendo a regra a sua vedação. ${ }^{30}$ Além disso circunscreve a utilização do mecanismo apenas às relações que forem hierárquicas $\mathrm{e}$, conseqüentemente, entre órgãos.

\section{Inconstitucionalidades e ilegalidades da submissão das agências ao recurso hierárquico impróprio e à revisão ex officio}

Como visto, os métodos através dos quais pode ser exercida a tutela sobre as entidades da Administração Indireta devem ser, de acordo com a melhor doutrina, restritos às hipóteses previstas expressamente em lei. Não podem, portanto, ser respaldados em simples previsão genérica de supervisão ministerial, à qual, conforme as lições de JESSÉ TORRES PEREIRA JÚNIOR, "não corresponde um 'nomen juris' definido" ${ }^{31}$ e, conseqüentemente, dela não se pode extrair a previsão expressa do seu cabimento; tampouco na previsão da avocatória presidencial, incompatível com a natureza desse instituto e com a regulação especial trazida pelas leis das agências reguladoras. Por isso, tanto o recurso hierárquico impróprio quanto a revisão ex officio pelo Executivo Central deveriam possuir previsão legal expressa, não sendo um parecer-normativo da AGU a sede adequada para criá-los.

No Brasil, entretanto, não há lei alguma que preveja expressamente o cabimento de recurso perante o Ministério competente ou o Chefe do Executivo contra ato emanado das agências reguladoras independentes, tampouco a revisão ex officio de suas decisões. Assim, de plano, a admissão de tamanha intervenção dos Ministérios sobre as agências reguladoras contraria as leis delas instituidoras, que, ou vedaram expressamente o recurso hierárquico impróprio ao nomear a agência como a última instância administrativa, ou já previram como instâncias recursais exclusivamente as de natureza interna, ou as nomearam como entidades/autoridades administrativas independentes, ou, ainda, pelo simples fato de lhes ter concedido autonomia sem a exceção contemplada no parecer-normativo.

\footnotetext{
30 "Art. 15. Será permitida, em caráter excepcional e por motivos relevantes devidamente justificados, a avocação temporária de competência atribuida a órgão hierarquicamente inferior."
}

31 PEREIRA JÚNIOR, Jessé Torres. Supervisāo ministerial e tutela administrativa, p. 127. 
O que se deve notar é que pouco importa se nesta ou naquela agência está ou não expressamente excluída a interposição de recurso hierárquico impróprio. Como já visto, não é a sua vedação que deve ser expressa, mas a sua admissão (pas de tutelle sans texte). O próprio Decreto-lei $n^{\circ} 200 / 67$, aplicável às agências reguladoras no que não contrariar as suas leis específicas, não inclui os recursos hierárquicos impróprios entre os mecanismos de supervisão ministerial disciplinados por seus arts. 19 a $29 .{ }^{32}$

No Brasil, especialmente em âmbito federal, existem leis diferenciadas voltadas à regulação individual dos vários setores da economia brasileira, cada qual com as suas peculiaridades, demandas e expectativas inerentes. E se estas leis não prevêem o cabimento do recurso hierárquico impróprio, não pode uma interpretação extensiva, arbitrária e sem base legal do que seja supervisão ministerial impor o seu cabimento contra as decisōes emanadas das agências.

Do ponto de vista constitucional, também o parecer-normativo não pode subsistir, por duas razões distintas. A primeira, em virtude da violação da distinção constitucional entre Administraçāo Direta e Administração Indireta, igualando organizacionalmente as duas ao prever a ampla e subjetiva possibilidade de intervenção ministerial (por recurso ou de ofício) sobre as suas decisōes, equiparando-as fática e juridicamente aos órgāos hierarquicamente subordinados da Administração Direta, equiparação esta que nem o próprio Decreto-lei nº 200/67 faz. ${ }^{33}$ Em segundo lugar, o parecer-normativo também é inconstitucional por violar os princípios constitucionais da eficiência, economicidade e celeridade dos processos, princípios estes que voltarão a ser abordados no próximo tópico.

Ademais, em relação especificamente à ANP e à ANATEL, viola a previsão constitucional de um órgão regulador para estes setores, uma vez que, na prática, o parecer-normativo institui a regulação tríplice de cada ramo da economia, pelas agências, pelo Ministério e pela AGU, como árbitro final, este último que sequer possui competência técnica especializada. O mesmo se aplica aos demais ramos da economia, cujas agências reguladoras foram criadas com base na previsão do caráter eminentemente regulador do Estado (art. 174).

Por derradeiro, o parecer-normativo, subvertendo a distinção entre juízo de admissibilidade e mérito, fixa requisito que ao mesmo tempo é de admissibilidade

\footnotetext{
32 Repisamos ainda que os arts. 84, II e 87, parágrafo único, I, CF também não se prestam para uma suposta constitucionalizaçāo dos recursos hierárquicos impróprios, uma vez que a coordenaçāo, direçāo e supervisão ali previstas devem ser entendidas, em relaçāo às entidades da Administração Indireta, nāo como hierarquia, mas como tutela administrativa, instituto por definição constrito ao que o legislador expressamente estabelecer. E mais, em virtude do próprio Princípio da Legalidade, a supervisão e a coordenação da Administração Indireta pelo Presidente da República e pelos Ministros de Estado deve, obviamente, ser entendida como "supervisão e a coordenação" na forma da lei.

33 Como visto acima, o Decreto-lei $n^{9} 200 / 67$ atribui tratamento distinto entre a Administraçāo Direta e a Indireta. A supervisão ministerial sobre os órgãos da Administração Direta e Indireta, por exemplo, é prevista em artigos distintos. Além disso, o inciso IV do seu art. 26 dispõe que tal supervisão deverá assegurar a autonomia administrativa, operacional e financeira da entidade da Administração Indireta, não fazendo a mesma ressalva para os órgãos da Administração direta.
} 
e de procedência do mérito da intervenção ministerial. O recurso hierárquico impróprio será cabível se a agência estiver violando políticas públicas; se ela as estiver violando, todavia, o recurso necessariamente terá que ser julgado procedente. Isso faz com que, apesar dos ares de excepcionalidade que o parecer-normativo parece querer dar o recurso administrativo por ele instituído, ao fundir o seu juízo de admissibilidade com o juízo de mérito na verdade cria um recurso com requisito de admissibilidade genérico e abrangente.

\section{Violação aos princípios constitucionais da celeridade do processo, da economicidade e da eficiência}

O parecer-normativo da AGU padece também de inconstitucionalidade por violar os princípios constitucionais da celeridade do processo, da economicidade e da eficiência. Isso porque, na prática, admitir o cabimento do recurso hierárquico impróprio equivale a criar no mínimo mais duas instâncias de julgamento das demandas originárias das agências reguladoras, a saber, os Ministérios ou o Presidente da República, e a AGU, tornando os processos administrativos mais longos, mais caros e, por conseguinte, menos efetivos.

A hipótese em comento pode muito bem ser comparada ao que já ocorre com relação aos recursos especiais e extraordinários do processo civil, criados não para servirem como um $3^{\circ}$ grau de jurisdição, mas para proteger e dar interpretação uniforme às leis federais e às normas constitucionais. No entanto, o que se vê é que as partes sucumbentes, mesmo quando não há qualquer violação à lei federal ou à Constituição, quase sempre interpõem os referidos recursos, obrigando a sua análise pelas Cortes superiores.

É o que acontecerá no âmbito das decisōes das agências reguladoras, a prevalecer o entendimento esposado no referido parecer-normativo, prejudicando todo o arcabouço de regulação célere preconizado pelas leis das agências reguladoras e pelo art. 174, CF. Os Ministérios competentes tornar-se-ão um terceiro grau de jurisdição para praticamente todas as decisões proferidas pelas agências, já que os administrados, ou os próprios Ministérios, sempre poderão criar um meio de reconduzir a sua inconformidade com relação às decisões das Agências à violação de alguma finalidade pública ou à extrapolação da competência.

Perceba-se que a recondução mencionada acima será muito simples, uma vez que as políticas nacionais são normalmente fluidas e genéricas, e, especialmente, porque a delimitação das competências das Agências reguladoras e do Chefe do Executivo nessa seara é muito difícil. Demonstrada essa premissa, torna-se evidente a violação dos princípios constitucionais acima destacados, conforme se verá abaixo.

A necessidade de observância aos princípios da eficiência e da economicidade está prevista nos arts. 37 e 70 da Constituição Federal. Quanto ao primeiro, 
MARCOS JURUENA VILLELA SOUTO ensina que o princípio da eficiência impõe o "atrelamento da ação à qualidade do resultado" e que "os atos da Administração Pública devem atender aos padrões de qualidade e metas previamente fixados, com a busca da melhor relação custo/beneficio (donde decorrem os princípios da legitimidade e da economicidade [...]". ${ }^{34} \mathrm{O}$ princípio da economicidade, por sua vez, é técnico e envolve a "obtenção da melhor relação de custo benefício, da adequação dos capitais empregados aos resultados obtidos". ${ }^{35}$

Assim, de um lado temos a necessidade de que a Administração Pública aja com eficiência e economia, e de outro, a constataçāo de que um dos meios de assim proceder é através da descentralização de suas competências, como, por exemplo, mediante a criação das Agências Reguladoras. Mas, como visto nos tópicos anteriores, de nada adianta que sejam criadas tais entidades, com vistas a tornar a administração pública mais eficiente, se, na prática, todas as suas decisões poderão ser recorridas ou revistas por outro órgão da Administração Pública. Com a disciplina criada pelo parecer-normativo, a própria existência das agências reguladoras consistirá em perda de tempo e de dinheiro com essas estruturas, já que, em última análise, as convola em mera etapa da decisão a ser, afinal, proferida, pelo Ministério e pela AGU.

Com efeito, a mera criação de autarquia ou de qualquer outra espécie de ente da Administraçāo Indireta, sem que possua um grau de razoável autonomia para desenvolver suas atribuições, não torna o seu desempenho mais ágil e eficiente, não as caracterizando como entidades descentralizadas em sentido material, ou seja, efetivo. Note-se que o próprio espírito originário das autarquias já denotava a exigência da autonomia frente ao Executivo central porque, se não fosse para ser assim, não haveria razão para que o Estado criasse uma pessoa jurídica para desempenhar parte das suas funçōes, bastando que criasse mais um órgão integrante da sua estrutura hierárquica, mas não uma autarquia, cuja própria etimologia já denota a efetiva autonomia de que deveria gozar.

Em outras palavras: apresenta-se ineficiente e anti-econômico que coexistam três estruturas administrativas diferentes - as Agências, os Ministérios e a AGU -, com funcionários, mobiliário, chefes de departamento etc., próprios, com vistas à realização da mesma atividade. A eficiência e a economicidade impõem, portanto, que se gaste o mínimo de recursos possíveis para que se atinja a finalidade da administração com qualidade e, por conseguinte, a redução do número de órgãos competentes para avaliar as mesmas questões, conferindo-as ao órgão tecnicamente mais especializado.

Também merece ser citado como violado pelo parecer-normativo o princípio constitucional da segurança jurídica (art. $5^{\circ}$, caput, CF), em sua vertente institucional, que impõe ao Estado a preservação mínima e não meramente nominal das

34 SOUTO, Marcos Juruena Villela. Direito administrativo regulatório, p. 183.

35 SOUTO, Marcos Juruena Villela. Direito administrativo regulatório, p. 185. 
instituiçōes nas quais os particulares se fiaram ao tomar decisões essenciais para suas vidas e patrimônios, no caso, o investimento em setores econômicos regulados por entidades independentes, sem subordinação hierárquica - própria ou muito menos imprópria - aos titulares de poder político-eleitoral.

Já o princípio constitucional da celeridade do processo, por sua vez, encontrase previsto no art. $5^{\circ}$, inciso LXXVIII: “Art. $5^{\circ}$, LXXVIII. A todos, no âmbito judicial $e$ administrativo, são assegurados a razoável duração do processo e os meios que garantam a celeridade de sua tramitaçâo." Como direito fundamental previsto no bojo do art. $5^{\circ}$ da Constituição, a celeridade do processo possui aplicabilidade imediata, nos termos do $\$ 1^{\circ}$ do referido artigo, e, ainda, da mesma forma que os princípios da eficiência, economicidade e segurança jurídica, no mínimo, uma eficácia negativa, autorizando a declaração de invalidade de todas as normas que sejam contrárias ao fim pretendido pelo princípio. A eficácia negativa desses princípios constitucionais impōe, portanto, que seja declarada inválida toda e qualquer norma que aumente irrazoavelmente o tempo do processo e a multiplicidade de instâncias, como é o caso do parecer-normativo.

\section{8 não-acolhimento pela CF/88 de um regime presidencialista napoleônico}

Em seu parecer-normativo, a AGU defende também que a supervisão ministerial nos termos pretendidos, isto é, através da interposição dos recursos hierárquicos impróprios e de revisão ministerial ex officio, consubstanciaria "um traço essencial do regime presidencialista vigente" (p. 2 do parecer-normativo).

Todavia, ao contrário do sustentado pela AGU, não é a forma de governo genericamente adotada que determina a amplitude das competências do Executivo central, sobretudo de forma tão específica a ponto de atribuir-lhe implicitamente a competência para o julgamento dos recursos hierárquicos impróprios ou para a revisão ex officio, mas a Constituição Federal, ao enumerar as competências do Presidente da República, e as leis que disciplinam e limitam o seu exercício ex $v i$ do Princípio da Legalidade.

Assim, muito embora cada forma de governo possua as suas características gerais, estas não são suficientes para que se possa definir, com detalhes, as funçōes e competências de cada Poder estatal. Não há que se falar, portanto, que o recurso hierárquico impróprio é intrínseco à idéia do presidencialismo, como se, apenas em virtude da adoção desse regime, fosse dado ao Presidente fazer o que bem entender, ao arrepio da Constituição Federal e da legislação ordinária, sobre todas as entidades - dotadas de personalidade jurídica própria e, portanto, também protegidas pelo Princípio da Legalidade (art. 5º II, CF) - da Administração Indireta.

A idéia de que os Chefes do Poder Executivo devem tudo poder e em tudo se imiscuir, inclusive em relação a entidades que, por força de lei, possuem prerroga- 
tivas e funçōes próprias, é corolário de uma concepção imperial do Poder Executivo, que remonta à introdução do presidencialismo na América Latina ${ }^{36}$ e não de um Estado Democrático de Direito que se prega ser o Brasil nos dias de hoje.

Aliás, em um país cuja história foi marcada recentemente por golpes de Estado e regimes ditatoriais, a adoção de tal teoria equivaleria a abandonar importante conquista obtida pelo povo brasileiro, conquista esta que precisa ser reafirmada diariamente, qual seja, o respeito à Constituição Federal e à delimitação dos poderes estatais nela prevista.

Em um Estado Democrático de Direito deve ser respeitada uma série de direitos fundamentais e se devem controlar as agências apenas de acordo com os meios previstos em lei, sem a possibilidade de se rever toda e qualquer decisão com base em alegada violação à política pública governista.

VITAL MOREIRA, em trabalho específico sobre as agências reguladoras no Brasil, ${ }^{37}$ observou com naturalidade que "a animosidade do governo federal contra as agências reguladoras é fácil de explicar, baseando-se, por um lado, na vontade de remover as personalidades deixadas pelo Governo precedente e de substituí-las por outras próximas do novo poder político, e por outro lado, numa concepção mais marcadamente 'política' e voluntarista da regulação, sobretudo no que se refere às tarifas dos serviços públicos, que o governo gostaria de controlar, dado que a sua subida afecta a sua base social de apoio".

Refutando a alegação "de que, como o regime é presidencialista, o poder delas não pode se sobrepor ao do Executivo", o autor prossegue afirmando que "este argumento não resiste, porém, a um simples exercício de reflexão. De fato, as agências reguladoras independentes são uma criação dos Estados Unidos, a mais clássica expressão de um regime presidencialista, onde elas existem há mais de um século". 38

\footnotetext{
36 “'O regime dos caudilhos', diz o autor peruano [F. Garcia-Calderón], 'conduz ao governo presidencial. [...] Tudo, assinala ele, está nas māos do Presidente - o exército, a marinha, a administração da justiça, as maiorias no Congresso, a administraçāo civil e financeira, 'exatamente como, antes da era republicana, a direçāo suprema pertencia ao vice-rei'. Assim, a forma presidencialista de governo foi o resultado lógico do domínio arbitrário dos caudilhos, em forma constitucional. [...] O que alcançaram, na prática, foi colocar poderes ilimitados nas māos de um homem que o Congresso nāo podia controlar, e que, por meio de sofismas ou da violência, algumas vezes obedecendo a letra da Constituição e sempre traindo o seu espírito, quando isso the convinha, agiu despoliticamente em seu próprio interesse e no de seus satélites, sem qualquer consideração pelas liberdades do povo. [...] Estes aspectos da política latino-americana exercem considerável influência no governo republicano brasileiro, pois, ao adotar o regime presidencialista em sua constituição republicana, o Brasil tornou-se herdeiro colateral da tradição caudilhesca" (HAMBLOCH, Ernest. Sua majestade o Presidente do Brasil. Brasília: Universidade de Brasília, 1981, p. 47-48).

3: MOREIRA, Vital. Agências reguladoras independentes em xeque no Brasil. In: MARQUES, Maria Manuel Leitão; MOREIRA, Vital. A mão visível: mercado e regulação. Coimbra: Almedina, 2003, p. 228, grifamos.

38 MOREIRA, Vital. Agências reguladoras independentes em xeque no Brasil. In: MARQUES, Maria Manuel Leitão; MOREIRA, Vital. A mão visivel: mercado e regulação. Coimbra: Almedina, 2003, p. 228, grifamos.
} 
A Constituição de 1988 não permite que a ingerência do Chefe do Poder Executivo sobre as Agências chegue ao ponto de excluir, na prática, a sua autonomia, como, inclusive, já foi verificado pela doutrina brasileira com relação às antigas autarquias, fenômeno este que chegou a ser denominado de "desautarquização das autarquias", não mais compatível com o Estado Democrático de Direito e com a constitucionalização da diferença entre a Administração Direta e Administração Indireta (p. ex., no art. 37, caput).

A esse respeito, DIOGO DE FIGUEIREDO MOREIRA NETO nota perspicazmente, em relação às modernas autarquias reguladoras independentes, que

"a descentralização autárquica, depois de um certo declínio, ressurgiu restaurada, como a melhor solução encontrada para conciliar a atuação típica de Estado, no exercício de manifestaçōes imperativas, de regulaçāo e de controle, que demandam personalidade jurídica de direito público, com a flexibilidade negocial, que é proporcionada por uma ampliação da autonomia administrativa e financeira, pelo afastamento das burocracias típicas da administração direta e, sobretudo, como se exporá, pelo relativo isolamento de suas atividades administrativas em relação à arena políticopartidária". ${ }^{39}$

É desta maneira que as agências reguladoras constituem uma retomada da idéia inicial de autarquia, tendo o Legislador, se precavendo contra as distorçōes verificadas no passado, criado uma série de garantias institucionais em favor delas, entre as quais a autonomia funcional acima descrita, não tendo sequer se limitado à afirmação genérica dessa autonomia, mas também assegurado os meios concretos para o seu exercício através da atribuição de receitas próprias, "mandatos" fixos dos seus dirigentes, previsão de constituírem a última instância administrativa etc.

Assim, longe de constituir traço essencial do sistema presidencialista, a supervisão ministerial nos termos vislumbrados pelo parecer-normativo constitui afronta ao Estado Democrático de Direito e ao modelo de agências reguladoras adotado no Brasil, através das respectivas leis criadoras. A pretensão de controlar todas as decisões das agências reguladoras remonta, como visto, a uma idéia totalitária do Poder Executivo, aos moldes do regime napoleônico, este último curiosamente fundamentado na ausência de legitimidade do governo e no receio quanto à perda de poder. ${ }^{40}$

\footnotetext{
39 MOREIRA NETO, Diogo de Figueiredo. Agências reguladoras (descentralização e deslegalizaçāo): mutaçōes do direito administrativo. Rio de Janeiro: Renovar, 2000, p. 147.

40 Giglielmo Ferrero ensina que toda a trajetória de Napoleão Bonaparte foi caracterizada pelo medo. Nas palavras do autor, "a onipotência imperial, o patrão da Europa, o super-homem nietzchiano da lastimável literatura do século passado, tremia porque lhe faltava apoio dos dois gênios invisiveis, que unicamente podem dar ao poder a força de ter coragem: a legitimidade monárquica e a legitimidade democrática. Todas duas haviam desertado as Tulherias e o seu senhor, porque nem ele nem o seu governo tomavam a sério uma ou outra (FERRERO, Giglielmo. Potere. Milão: Gina Lombroso, 1959, p. 155-156).
} 


\section{O papel da Advocacia-Geral da União na solução de conflitos entre setores da Administração Pública Federal}

A grande setorização e especialização dos centros estatais de poder torna inevitável a necessidade de criação de mecanismos de coordenação entre estas diversas sedes, evitando-se conflitos quanto à interpretação de normas. Já se constata, na prática, uma série de conflitos, seja entre agências reguladoras com outras entidades da Administração Indireta ou com órgãos da Administração Direta, notadamente os Ministérios, seja entre agências reguladoras entre si, ou entre essas e os órgãos de defesa da concorrência etc. $O$ ideal seria que os órgãos e entidades cujas competências tenham potenciais pontos de atrito expedissem atos normativos conjuntos ou celebrassem convênios com vistas à prevenção de conflitos.

$\mathrm{Na}$ ausência desses mecanismos, parece-nos que a solução do conflito pode ser determinada, em alguns casos, e tão-somente no âmbito administrativo - sempre possível, portanto, a ação ao Judiciário pela entidade da Administração Indireta prejudicada ${ }^{41}$-, pela Advocacia-Geral da União, ${ }^{42}$ com base na competência que lhe é atribuída pelos incisos X e XI do art. $4^{\circ}$ da Lei Complementar no $73 / 93 .{ }^{43}$

O controle exercido pela AGU, no entanto, deve sempre ser excepcional e pontual, ainda mais em se considerando as peculiaridades do modelo das agências reguladoras independentes, de forma a não se imiscuir, sob a escusa de uniformização de interpretação, na estruturação do arcabouço organizacional das entidades da Administração Indireta ou no próprio processo administrativo federal.

A esse respeito, CELSO CAMPILONGO, no que tange especificamente aos poderes de interpretação da AGU, conferidos pela Lei Complementar $n^{\circ} 73 / 93$, assevera que "a administração indireta - enquanto gênero, sendo a autarquia uma de suas espécies - não pode ter a sua configuração, em tese e a priori, restringida, como se não fosse mais possível criar pessoa jurídica de direito público com autonomia própria. Uma reforma no modelo geral de organização administrativa do Estado só poderia ser levada adiante por meio de emenda à Constituição Federal. Mais: como poderia a Lei Complementar 73/1993 versar sobre matéria de

\footnotetext{
4i No caso de todo o seu corpo jurídico estar impedido para atuar em razão de pertencer aos quadros da AGU, será possível a contratação de advogado privado para essa açāo específica, observada a Lei $n^{2}$ 8.666/93, como aliás já praticado por alguns Poderes sem corpo jurídico próprio em seus conflitos com o Poder Executivo, em que, naturalmente, não poderiam ser patrocinados pelos procuradores do Estado ou do Municipio respectivo, que integram o quadro funcional do Executivo.

42 A nossa opiniāo admitindo, em termos gerais, a coordenação jurídica da AGU já foi expressa em sede doutrinária (Agências Reguladoras... cit.), nos termos citados e, em parte criticados, no parecernormativo em comento. A nossa análise no momento versa, contudo, não sobre a competência em tese conferida à AGU, mas como ela foi concretamente exercida através do parecer-normativo.

43 "Art. $4^{2}$ São atribuiçōes do Advogado-Geral da Uniāo: [...] X - fixar a interpretaçāo da Constituição, das leis, dos tratados e demais atos normativos, a ser uniformemente seguida pelos órgāos e entidades da Administração Federal; XI - unificar a jurisprudência administrativa, garantir a correta aplicaçāo das leis, prevenir e dirimir as controvérsias entre os órgãos jurídicos da Administração Federal."
} 
organização administrativa (do art. 37 da CF), considerando-se que se presta a regulamentar competências da Advocacia-Geral da União?"44 Como se vê, a preocupação do jurista é a de que, através da competência de fixar a interpretação das leis, a AGU, extrapolando das suas finalidades, modifique as competências das entidades da Administração indireta, ao conferir-lhes interpretação extensiva ou restritiva.

Não se está aqui a negar a possibilidade de controle do AGU sobre estas entidades, mas defendendo uma interpretação do art. $4^{\circ}$ da Lei Complementar $n^{\circ}$ $73 / 93$ que se coadune com a distinção constitucional entre a Administração direta e a indireta e com a autonomia conferida às agências reguladoras, bem como a competência privativa do Congresso Nacional para legislar sobre processo administrativo federal (art. $22, \mathrm{I},{ }^{45} \mathrm{C} / \mathrm{C}$ art. $48^{46}$ da Constituição Federal).

A Lei Complementar n⿳0 73/93 não pode ser potencializada de forma a permitir, por vias transversas, a delegação de competência legislativa ao Chefe do Poder Executivo sobre processo administrativo federal. Se adotado o entendimento da AGU, o Presidente da República, respaldado em simples parecer e nada mais - e sem o devido controle pelo Congresso Nacional - seria legitimado a criar atos normativos sobre toda sorte de assuntos, vinculantes a toda a Administração Pública, direta e indireta, e, inclusive, sendo óbvio o geralmente largo espaço existente entre diversas interpretaçōes admissíveis e o caráter criativo da atividade hermenêutica, que não se limita, como acreditavam os pensadores do século XVIII, a apenas declarar/desvendar o que já estava contido na lei. ${ }^{47}$ Portanto, não pode a AGU, ou qualquer outro órgão da administração pública, decidir sobre processo administrativo federal ou organização administrativa, sobretudo para determinar o cabimento de recurso não previsto em lei, em sede de parecer-normativo com efeitos vinculantes.

44 Concorrência e regulaçāo no sistema financeiro. In: CAMPILONGO, Celso Fernandes; DA ROCHA, Jean Paul Veiga; MATTOS, Paula Todescan. Sāo Paulo: Max Limonad, 2002, p. 471 ss. Como exposto, ao contrário da posição desse autor, anuímos em tese com a competência conferida à AGU, mas com certos limites a serem observados nos casos concretos em que vier a ser exercida.

45 "Art. 22. Compete privativamente à Uniāo legislar sobre: I - direito civil, comercial, penal, processual, eleitoral, agrário, marítimo, aeronáutico, espacial e do trabalho."

46 "Art. 48. Cabe ao Congresso Nacional, com a sanção do Presidente da República, não exigida esta para o especificado nos arts. 49, 51 e 52, dispor sobre todas as matérias de competência da Uniāo, especialmente sobre."

47 Em relação aos procedimentos de validação pelos quais o intérprete testa as suas conjecturas hermenêuticas, elas se aproximam mais da lógica da probabilidade do que de uma lógica da verificação empírica. Mostrar que uma interpretação é mais provável à luz do que sabemos é diferente do que mostrar que uma conclusāo é verdadeira. A hermenêutica jurídica é uma disciplina argumentativa, dentro de uma lógica de incerteza e de probabilidade qualitativa, não uma verificação (RICOEUR, Paul. Teoria da interpretạ̧āo. Trad. Artur Morão. Lisboa: Ediçōes 70, 2000, p. 90). Como expōe Eros Roberto Grau, com base nas liçōes de Karl Larenz e Hermann Heller, "a lógica jurídica é a da escolha entre várias possibilidades corretas. Interpretar um texto normativo significa escolher uma entre várias interpretaçōes possiveis, de modo que a escolha seja apresentada como adequada. A norma não é objeto de demonstraçāo, mas de justificação. Por isso, a alternativa verdadeiro/falso é estranha ao Direito; no Direito há apenas o aceitável (justificável). O sentido do justo comporta sempre mais de uma soluçāo" (GRAU, Eros Roberto. Ensaio e discurso sobre a interpretação/aplicação do direito. São Paulo: Malheiros, 2002, p. 88). 
Ademais, se deve atentar para que a solução dos eventuais conflitos entre agências e Poder Executivo central deveria ser conduzida de maneira minimamente razoável do ponto de vista da imparcialidade - jamais pelo advogado do próprio órgão que diz ter a sua competência usurpada. LUIS ROBERTO BARROSO, a respeito da competência jurisdicional da Administração Pública, expõe que

"o fato de a própria Administração Pública, muitas vezes, dispor de competência para decidir disputas com o particular, sempre com possibilidade de revisão pelo Judiciário e no âmbito do contencioso administrativo, não afasta a exigência de imparcialidade do órgão julgador. Aliás, como a própria expressão revela, o contencioso administrativo exige um procedimento específico - em que são asseguradas as garantias decorrentes do devido processo legal -, e órgãos próprios, em geral de formação mista, com competência decisória atribuída por lei. Junte-se a isso o conceito de responsabilidade do julgador, desenvolvido pela doutrina administrativista exatamente para reforçar a imparcialidade das decisōes da Administração Pública" ${ }^{48}$

Além disso, muito embora as agências reguladoras tenham, de fato, que respeitar as políticas públicas fixadas pela Constituição, pelas suas Leis de criação e pelo Executivo central, o seu eventual descumprimento não pode ser razão para a intervenção. Ora, não pode o Executivo central, com base em alegada usurpação da sua competência - alegação esta respaldada em parecer-normativo de um Advogado-Geral hierarquicamente subordinado ao Chefe do Executivo central -, intervir no órgão que diz extrapolar as suas competências.

Em outras palavras, não é o fato de uma entidade violar a competência de outra que legitima que seja a entidade violada o juiz da suposta invasão de competência e a competente para coercitivamente aplicar as correções que julgar necessárias, sob pena de ficar totalmente falseada a autonomia daquela.

O foro por excelência para a resolução desses conflitos é o Poder Judiciário, em virtude da sua imparcialidade frente às partes em contenda, conforme salientado por MARIA SYLVIA ZANELLA DI PIETRO, ao expor que nos casos em que não houver previsão expressa em lei para o recurso hierárquico impróprio ou para outros tipos de tutela, como a revisão ex officio, "prolatada a decisão final pelo dirigente da entidade, somente cabe ao interessado recorrer ao Poder Judiciário". ${ }^{9}$

A respeito dos controles exercidos sobre as atividades das agências reguladoras, DIOGENES GASPARINI salienta que "esses controles não vedam nem inibem, por parte da autarquia, a propositura de medidas judiciais contra atos

48 BARROSO, Luís Roberto. Impossibilidade de auto-execuçāo dos créditos do Poder Público sem intervençāo do Judiciário. Dever de Motivação dos Atos Administrativos Restritivos de Direitos. In: Temas de direito constitucional. Rio de Janeiro: Renovar v. 2, no prelo.

49 DI PIETRO, Maria Sylvia. Direito administrativo, p. 411. 
abusivos da Administraçāo Pública a que pertence. A autarquia é pessoa jurídica de direito público e como pessoa é sujeito de direitos e obrigaçōes. Pode, ademais, não se conformar com os atos de tutela, por entendê-los ilegais, e tomar, em juízo, as medidas cabíveis com o fito de anulá-los". ${ }^{50}$ No mesmo sentido, CELSO ANTÔNIO BANDEIRA DE MELLO ensina que "as pessoas que prosseguem a atividade descentralizada podem pleitear em juízo, em nome próprio, até mesmo contra o Estado". ${ }^{51}$

Devemos também considerar a enorme fluidez do tema da divisão de competências entre agências e Poder Executivo central, pois envolve a delimitação do que seja fixar uma política pública e do que seja implementar tais políticas. Em vista da impossibilidade de uma absoluta delimitação de tais competências, tornase evidente a facilidade em se argumentar que a Agência usurpou competências do Poder Executivo central e vice-versa, o que tornaria em tese possível o recurso contra toda e qualquer decisão das Agências Reguladoras.

Além disso, as políticas públicas às quais as agências reguladoras são vinculadas não são fixadas em princípio pelo Ministro ou pelo Presidente da República, mas por conselhos setoriais. E são estabelecidas formalmente, através de resoluções e portarias, e não por mera opinião, a ser referendada ou não pela AGU. Assim, mesmo que fosse possível admitir o cabimento dos recursos hierárquicos impróprios, eventual alegação de violação de política pública não poderia ser respaldada em previsões genéricas, mas em lei, portaria ou resolução específica.

A competência para a fixação de políticas públicas pelo Executivo central, portanto, não pode minar todo $o$ arcabouço das agências reguladoras, tampouco tornar-se uma panacéia e uma desculpa para modificar uma decisão da agência sempre que for contrária aos interesses do Executivo central. $O$ órgão julgador de eventuais conflitos de competência deve ser o Judiciário, não um órgão do próprio Executivo central, que é parte diretamente interessada no conflito, o que viola inclusive os princípios do devido processo legal. O fato de ser uma pessoa jurídica ligada à União em nada lhe retira isto, pois possui personalidade jurídica - e, portanto, direitos e prerrogativas - próprias.

Assim, muito embora reconheçamos a existência de competência da AGU para fixar a interpretação de leis e atos normativos, entendemos que essa competência só deve ser exercida excepcionalmente e com toda a cautela para não deturpar a finalidade das leis interpretadas ou para criar, no caso concreto, competências não previstas expressamente em lei, ou, ainda, usurpar competência privativa do Congresso Nacional para legislar sobre processo administrativo, aí inclusa, naturalmente, a matéria recursal.

50 DI PIETRO, Maria Sylvia. Direito administrativo, p. 226.

51 MELLO, Celso Antônio Bandeira de. Natureza e regime jurídico das autarquias. São Paulo: RT, 1968, p. $81-82$. 


\section{Impossibilidade de a AGU declarar supostas inconstitucionalidades das leis das agências}

Conforme demonstrado, a AGU, através de uma exegese dissonante com a idéia de supervisão presidencial e ministerial prevista pela Constituição Federal e com o próprio modelo brasileiro das agências reguladoras, afirmou o cabimento de recurso hierárquico impróprio e de recurso ex officio contra as decisões das autarquias que alegadamente violassem as políticas públicas fixadas pelo Executivo Central.

Com base nessa interpretação, seria lícito ao Executivo central descumprir deliberadamente os dispositivos das leis das agências reguladoras que lhe fossem contrárias, notadamente aqueles dispositivos que prevejam a autonomia das agências frente ao Executivo central, a sua condição de autarquia especial ou mesmo de única instância administrativa de julgamento.

Ao proceder dessa forma, a AGU, por via indireta, acabou por declarar a inconstitucionalidade de alguns dos dispositivos das leis criadoras das agências reguladoras, por serem contrários à sua interpretação constitucional equivocada e descontextualizada de supervisão ministerial e de presidencialismo. $O$ parecernormativo claramente considera incompatível com a Constituição que uma entidade da Administração Indireta seja, como dispõem as leis das agências reguladoras, a última instância administrativa de julgamento, nāo cabendo, portanto, recurso hierárquico impróprio em qualquer hipótese.

Parte da doutrina brasileira, contudo, sustenta não ser dado ao Poder Executivo, através de quaisquer dos seus agentes, descumprir leis sob o argumento da sua inconstitucionalidade, uma vez que o Chefe do Executivo tem competência para propor ação direta de inconstitucionalidade perante o STF. Ora, se os legitimados pelo art. 103 da Constituição podem pleitear, perante um órgāo isento e imparcial - o Supremo Tribunal Federal -, a declaração da inconstitucionalidade da lei, sendo possível, ademais, o pedido de medida liminar, nāo há razão para que possa optar por simplesmente descumpri-la, com graves danos à segurança jurídica, à estabilidade das relaçōes jurídicas e à publicidade das normas jurídicas. ${ }^{52}$

Portanto, a conclusão inarredável a que se chega é que a Advocacia-Geral da União ou o Presidente da República não têm competência para determinar, expressa ou implicitamente, como o fizeram através do parecer-normativo em

52 Nas palavras de GILMAR FERREIRA MENDES, "o modelo de ampla legitimação consagrado no art. 103 da Constituição de 1988 não se compatibiliza, certamente, com o recurso a essa medida de quase desforço concernente ao descumprimento pelo Executivo da lei considerada inconstitucional. Se o Presidente da República - ou, eventualmente, o Governador do Estado - está legitimado a propor açāo direta de inconstitucionalidade perante o Supremo Tribunal Federal, inclusive com pedido de medida cautelar, não se afigura legítimo que deixe de utilizar essa faculdade ordinária para valer-se de recurso excepcional [...]". MENDES, Gilmar Ferreira. Jurisdição constitucional: o controle abstrato de normas no Brasil e na Alemanha. Sāo Paulo: Saraiva, 1998, p. 133. 
questão, o descumprimento de determinadas leis, por mais inconstitucionais que o sejam, o que não nos parece de forma alguma ser o caso.

\section{Conclusões}

O exposto no presente trabalho pode ser condensado através das seguintes assertivas objetivas:

1. Ao admitir a intervenção dos Ministérios nas agências reguladoras (por recurso hierárquico impróprio ou ex officio) sob o argumento de violação das políticas públicas do Executivo central, o parecer-normativo abre ampla válvula para interferência nessas entidades, ainda mais se considerando a extrema fluidez da distinção entre formulação de política pública e a sua execução e o fato de ter equiparado o juízo de admissibilidade ao mérito do recurso.

2. Não é o fato de uma entidade violar a competência de outra que legitima que seja a entidade violada o juiz da suposta invasão de competência e a competente para coercitivamente aplicar as correções que julgar necessárias, sob pena de ficar totalmente falseada a autonomia daquela e violado o princípio da imparcialidade.

3. O parecer-normativo contraria as leis das agências reguladoras que lhes assegura a posição de última instância administrativa.

4. O recurso hierárquico impróprio não pode, segundo inclusive a jurisprudência do STF e do STJ, ser genericamente extraído da supervisão ministerial ou, muito menos, do regime presidencialista, sendo imprescindível a sua previsão legal expressa e específica.

5. Ao julgar a ADIN 1949-0, que versava justamente sobre as agências reguladoras, o STF expressamente afirmou que o Direito Brasileiro não acolheu uma visão imperial ou napoleônica do presidencialismo, até porque, é justamente nos EUA, país presidencialista por excelência, que as agências mais possuem garantias de autonomia frente ao Executivo central.

6. A admissão de recursos hierárquicos impróprios deitaria por terra todo $o$ arcabouço institucional de independência traçado pelo ordenamento jurídico para as agências reguladoras.

7. O próprio Decreto-lei $n^{9} 200 / 67$, ao enunciar os diversos instrumentos de supervisão ministerial (art. 26, parágrafo único), não faz qualquer referência ao recurso hierárquico impróprio ou à revisão ex officio, e, de toda maneira, as leis das agências reguladoras seriam posteriores e especiais em relação a ele. 
8. A supervisão ministerial tem previsão constitucional, mas a Constituição não define o que seja e também contempla a figura da Administração Indireta (ex., art. 37, caput), o que pressupõe a descentralização, ou seja, a inexistência de relação hierárquica.

9. Ainda que a avocação presidencial prevista no Decreto-lei $n^{\circ} 200 / 67$ fosse aplicável às leis das agências reguladoras, não poderia ser utilizada como argumento a favor dos recursos hierárquicos impróprios ou da revisão ex officio, já que só pode ocorrer quando o ato a ser praticado pelo órgão inferior ainda não se consumou, constituindo, outrossim, deslocamento geral e abstrato de competência em determinada matéria.

10. De toda sorte, a Lei do Processo Administrativo Federal (Lei $\mathrm{n}^{\mathrm{o}}$ 9.784/99) em seu art. 15 coloca a avocação como um instituto de utilização excepcional, temporária e apenas entre órgãos com relação hierárquica, sendo a sua vedação a regra.

11. O parecer-normativo viola os princípios constitucionais da eficiência, economicidade, legalidade e celeridade dos processos, ao criar três instâncias para tratar da mesma matéria, criando inclusive recursos do processo administrativo não previstos em lei, conforme já reprovado pela jurisprudência do STJ.

12. Em relação especificamente à ANP e ANATEL, o parecer-normativo viola a previsão constitucional de um órgão regulador para estes setores, uma vez que, na prática, institui a regulação tríplice de cada ramo da economia, pelas agências, pelo Ministério e pela AGU, como árbitro final e sobre-regulador.

13. A AGU pode uniformizar a interpretação na Administração Pública federal, desde que não desvirtue o arcabouço organizacional de entidades da Administração Indireta, crie normas de processo administrativo ou afaste a aplicação de leis por ela reputadas inconstitucionais. 